\title{
INTRA-GOVERNMENTAL ACTIVITIES OF THE UNITED STATES TO FOSTER HEMISPHERIC TRADE
}

\author{
John E. Lockwood* and LuthrR Ely Smith, Jr. $\dagger$
}

With the inauguration of President Roosevelt and the announcement of the Good Neighbor policy toward the nations of the Western Hemisphere, the United States Government embarked on an active program to develop a sound, well-balanced economy in the Americas. The outbreak of the war in Europe necessitated the acceleration of the program since it became increasingly apparent that the future of each of the twenty-one American republics was dependent upon the fostering and maintenance of Hemisphere relationships. The involvement of the nations of the Hemisphere in the war means that solidarity and oneness of purpose are now a matter of life and death.

Some of the more important aims of the Good Neighbor policy in the economic field include: (a) relaxing restrictions on inter-American trade; (b) developing complementary agricultural products; (c) solving the problem of agricultural surpluses; (d) extending financial assistance to promote inter-American trade; (e) improving transportation facilities; and (f) bolstering the defenses of the Americas by building up reserves of strategic materials and preventing them from reaching unfriendly powers, and by preventing unfriendly powers from undermining the Good Neighbor policy with funds derived from commerce with the United States. War in the Pacific has restricted our source of supply of many critical and strategic materials to the Hemisphere. For the attainment of these objectives, lines of action have been developed by a very considerable number of agencies of the United States Government. To present an integrated picture, in broad outline, of these varied activities is the purpose of this article.

\section{Removing Trade Barriers}

One of the most important phases of the inter-American program has been the negotiation of reciprocal trade agreements. Such agreements are designed to promote foreign trade by removing or relaxing excessive trade restrictions. Authority to enter

- B.A., 1925, Williams College; LL.B., I928, Harvard University. Member of the New York State Bar. General Counsel, Office of Coordinator of Inter-American Affairs, since 1940. Formerly partner, Milbank, Tweed \& Hope, Attys., New York City; Law Secretary to Mr. Justice Holmes, I928-r929.

† B.A., 1934, Amherst College; LL.B., 1937, Yale University. Member of the Missouri Bar. In the General Counsel's Office, Office of Coordinator of Inter-American Affairs, until enlistment in U. S. Army in December, r94r. 
into trade agreements is provided by the Trade Agreements Act, approved June I2, 1934. ${ }^{1}$ Under this Act, the President is authorized, upon the advice of the Department of State, the Department of Agriculture, and the Tariff Commission, to enter into trade agreements. Such agreements may modify existing tariff rates by reductions not in excess of $50 \%$. While the power to enter into trade agreements is not restricted to nations of the Western Hemisphere, I2 out of 20 have been with the other American republics. ${ }^{2}$ Intention to negotiate trade agreements with two other republics, Chile and Uruguay, has been announced. The recently announced agreement between the United States and Mexico contemplates the negotiation of a trade agreement. $^{3}$

The benefits of these agreements are not restricted to the countries actually signing the agreement, but are automatically extended to all of the American republics by virtue of the "most favored nation" principle. ${ }^{4}$ While export and import statistics are complicated by the war, the trade agreements already negotiated have resulted in increased trade. ${ }^{5}$

\section{The Development of Complementary Agricultural Products}

The development of agricultural products in the other American republics which are complementary to, and not competitive with, agricultural products grown in the United States has almost limitless possibilities. Huge areas in the other Americas have a tropical or semi-tropical climate. Many agricultural products which the United States has in the past purchased from the Netherlands Indies, India, Malaya, and other countries in the Far East can be profitably grown in the Western Hemisphere. The development of such products should do much to improve the living standards of the citizens of the other Americas, and at the same time assure the United States a near-by source of supply for essential agricultural products.

The first step in the development of agricultural products is the conducting of exploratory surveys and experiments to determine whether a particular product can be grown economically. To date comprehensive surveys ${ }^{6}$ have been made in Colom-

${ }^{1} 48$ STAT. 943 (r934), I9 U. S. C. $\$ 1351$ (1935), originally enacted for a period of three years and twice extended by 50 STAT. 24 (1937) (till June I2, 1940), 54 STAT. 107 (r940) (till June 12, 1943), 19 U. S. C. A. $\$ 1352$ (c) (Supp. I940).

${ }^{2}$ Namely, Cuba, Brazil, Haiti, Colombia, Honduras, Nicaragua, Guatemala, Costa Rica, El Salvador, Ecuador, Venezuela, Argentina. In addition, two treaties have been negotiated with Canada. For the dates on which these treaties were signed and became effective, see Darlington, The Operation of the Trade Agreements Program in Overcoming Barriers to Hemispheric Trade, infra, p. 696, n. 18.

3 Agreement, art. III, N. Y. Times, Nov. 20, 194I, p. 4 .

- The Trade Agreements Act provides that, except in the case of Cuba, concessions granted with respect to an article in a trade agreement shall apply to the same article when imported from a third country unless the third country discriminates against the United States. 48 STAT. 943 (1934), 19 U. S. C. \$135I (a) (2) (1935). See 6 FED. REg. 5687 (I94I), extending to all countries other than Germany the reduction in duties embodied in the Trade Agreement with Argentina.

'The Reciprocal Trade Agreements Program of the United States, State Dep'T Pub. No. 1470, ComMercial Policx Ser. No. 64 (I940) 5.

${ }^{\circ}$ Undertaken pursuant to 53 STAT. 652, 5 U. S. C. $\$ 118$ (c) (Supp. 1939), authorizing the President, when requested by the government of any American republic, to detail to it temporarily any person having special scientific or other technical or professional qualifications. 
bia, Cuba, Ecuador, Haiti, and Paraguay under the direction of the Department of Agriculture.

The Department of Agriculture has also undertaken extensive surveys to determine the possibilities of producing rubber in the Western Hemisphere. These surveys have been made in Brazil, Colombia, Costa Rica, Dominican Republic, Ecuador, El Salvador, Haiti, Guatemala, Honduras, Mexico, Peru, and Venezuela. ${ }^{7}$ In addition to the interest and financial assistance of the United States, the development of a rubber industry in the Western Hemisphere has been aided financially by the governments of Brazil, Costa Rica, Peru, and Venezuela, as well as by private corporations.

Although rubber is the agricultural product which has received the greatest attention of this Government, a start has been made toward the development of approximately I20 other complementary, non-competitive agricultural products. While most of this work is still in the survey and experimental stage, the Haitian survey has resulted in the establishment of the Haitian Development Corporation. ${ }^{8}$ This Corporation is a semi-government corporation and is managed by a board of six directors, three of whom must be citizens of the Republic of Haiti and three citizens of the United States. The purposes of the Corporation, as set forth in its charter, are:

The development and exploitation of all agricultural and other resources of Haiti, includ. ing, ( $\mathrm{I}$ ) growing and developing rubber, oil crops, spices, drug plants, food plants, forestry resources; (2) advancement of experimental work designed to improve existing crops, to develop means of combating and preventing plant diseases, and to determine the adaptability to cultivation in Haiti of agricultural crops; (3) the development of methods of processing agricultural crops, and the promotion of manufacturing and handicraft related to agriculture; and (4) the purchase and sale, both domestic and foreign, of agricultural and manufactured products of Haiti. ${ }^{9}$

The Corporation will, among other things, supervise the growing of rubber trees which have been developed with the cooperation of the Department of Agriculture. It is anticipated that the Corporation will also assist in the development of products new to Haiti, such as tropical spices, oils, drugs, and fibers. Successful management by the Corporation should make a substantial contribution toward an improved living standard for Haiti and at the same time furnish the United States with sizeable quantities of tropical products now imported from the Far East. ${ }^{10}$

Another important contribution to the development of American agriculture is the establishment by Congress of the Canal Zone Biological Area on Barro Colorado Island in Gatun Lake as a place where students may make observations and scientific investigations. $^{11}$ The Biological Area is administered by a Board of Directors ${ }^{12}$

\footnotetext{
${ }^{7}$ Made possible by a special appropriation of $\$ 500,000$ in the Second Deficiency Appropriation Act of 1940, 54 Stat. 639 (1940).

The Corporation's formation was announced by the Department of State on May 5, 194I.

${ }^{\circ}$ (I94I) 96 LE Moniteur 506.

${ }^{10}$ Fennell, Haiti Makes Rubber History, (July I94I) Agriculture in the AMrericas 7.

1154 Stat. 724 (1940), 48 U. S. C. A. \$138I, et seq. (Supp. 1940).

${ }^{12}$ Composed of the Secretaries of War, Agriculture, Interior, and the Smithsonian Institution, the President of the National Academy of Sciences, and three distinguished biologists of the United States
} 
which is charged with the responsibility for the construction and maintenance of laboratory and other facilities.

It is expected that rapid progress in this field will be made when the Institute of Tropical Agriculture is formally established..$^{13}$ The purposes and aims of the Institute will be the development of a well-balanced agricultural economy. It will gather information concerning the agricultural problems of the Americas, including methods of eradicating agricultural pests and diseases. It will also offer technical training to citizens of the American republics.

These programs, many of which have been sponsored by the Agricultural Division of the Coordinator of Inter-American Affairs, were formulated to serve the dual function of aiding in any war in which the Hemisphere should become involved and of planning for a balanced economy in the post-war world.

To familiarize the citizens of the American republics with the possibilities for developing complementary agricultural products and to apprize them of the progress being made, the Department of Agriculture publishes a popular monthly magazine entitled Agriculture in the Americas. It is planned to publish a similar magazine in Spanish to appear quarterly. In addition, the Department makes available to organizations throughout the country exhibits on agriculture in the other Americas and provides speakers to accompany and explain them.

\section{Agricultural Surpluses}

One of the most serious economic problems confronting the American republics is the problem of agricultural surpluses, chiefly in coffee, cocoa, wheat, cotton, and corn. In normal times these surplus crops furnish difficult problems. These problems have been greatly increased by the war and the blockade of Continental Europe, to which large amounts of these products are normally exported. The solution of these problems and the development of orderly production and marketing of these commodities is essential to the maintenance of a stable economy throughout the Americas.

The first important accomplishment in this field has been the Inter-American Coffee Agreement, which was signed on November 28, 1940, by fifteen American republics. ${ }^{14}$ Under this Agreement, the coffee requirements of the United States are allocated amongst the various coffee-producing nations of the Western Hemisphere. ${ }^{15}$ Supplementary legislation prohibits the importing of coffee into the United States for consumption except as provided in the Agreement. ${ }^{16}$ A similar agreement with

appointed by the President of the Academy with the approval of the four Secretaries. 54 STAT. 724, 48 U. S. C. $\$ 1383$ (Supp. 1940).

${ }^{13}$ Plans for such an institute have been worked out by the Inter-American Committee on Tropical Agriculture, composed of representatives from Bolivia, Brazil, Colombia, Costa Rica, Ecuador, Guatcmala, Peru, the United States, and Venezuela, appointed by the governing board of the Pan American Union.

${ }_{14}$ Brazil, Colombia, Costa Rica, Cuba, the Dominican Republic, Ecuador, El Salvador, Guatemala,

Haiti, Honduras, Mexico, Nicaragua, Peru, the United States, and Venezuela.

${ }_{16}$ The Agreement is discussed in Daniels, The Inter-American Coffee Agreement, infra p. 708.

${ }^{16}$ Pub. L. No. 33, 77th Cong., Ist Sess. (April II, 194I). See also Exec. Orders Nos. 8902, 8909, 6 Fed. REG. 4809, 4929 (I94I). 
respect to wheat is in the negotiation stage. Preliminary steps have been taken toward solving other surplus crop problems.

\section{Financial Assistance to Develop Inter-American Trade}

The financial problems in connection with inter-American trade have generally been handled by the Export-Import Bank. ${ }^{17}$ While the Bank has taken steps since its creation to promote and develop trade with the other Americas, its powers in this area have recently been greatly broadened. The Bank is now empowered to lend funds furnished by the Reconstruction Finance Corporation to assist in the development of the resources, the stabilization of the economies, and the orderly marketing of the products of the countries of the Western Hemisphere. ${ }^{18}$ The only limitation is the requirement that loans for such purposes shall not be in violation of international law nor exceed $\$ 500$ million outstanding at any one time.

The curtailment of trade with Europe, Asia, and Africa occasioned by the war, together with the acceleration of the Good Neighbor policy, has resulted in the Bank's concentrating on inter-American problems. As of November I, I94I, the Export-Import Bank had authorized loans to each of the other American republics except Guatemala, Honduras, and El Salvador. While all the loans have in view the development of inter-American trade, the activities may be roughly grouped into four classes:

(I) loans to provide dollar exchange to meet temporary critical conditions and thus make possible purchases of American exports;

(2) loans to develop noncompetitive resources which can be sold to the United States;

(3) loans to build productive public improvements which will improve living standards and thus make possible an expansion of trade with the United States; and

(4) loans to finance imports where special circumstances exist precluding private financing.

Loans of the first type were made during the first year of the war when the blockade forced the American republics to look to the United States for goods formerly purchased from Europe. Importers were unable to purchase through the ordinary commercial channels because of insufficient exports to the United States to furnish the necessary dollar exchange. ${ }^{19}$ Except for a few instances, this situation no longer exists due to heavy purchases of defense materials both by private business in the United States and by the Metals Reserve Company, the Rubber Reserve Corporation, and the Defense Supplies Corporation. ${ }^{20}$

${ }^{17}$ The Export-Import Bank was created by Exec. Order No. 6581, Feb. 2, 1934, issued pursuant to the National Industrial Recovery Act, 48 STAT. 195 (1933), I5 U. S. C. \$702. The Bank was recognized by Congress in January, 1935, when its powers were broadened and its continuance authorized to June 16, 1937. 49 Stat. 4 (I935). The Bank's corporate existence now extends to Jan. 22, I947, or such earlier date as the President may fix. 54 STAT. 962, I5 U. S. C. A. $\$ 7$ r3 (b) (Supp. 1940).

${ }^{18} 54$ SтAт. 96r, I5 U. S. C. A. \$606(b) (Supp. 1940).

${ }^{10}$ Pierson, $A$ Report to the American People, 4 For. Commerce WeekIx, Sept. 6, I94I, p. 3.

${ }^{20} I d$. pp. 3-4. For a further discussion of the Bank's activities, see Fetter, The Role of Governmental Credit in Hemispheric Trade, infra at p. 723 et seq. 
Loans of the second and third types are expected to be of great value in developing a mutually prosperous trade between the American republics. Loans of these types include loans to help finance the construction of such important roads as the Pan American Highway, the development of rubber and other noncompetitive agricultural products, and the development of new industries. Such loans are generally for the purpose of enabling the borrower to purchase machinery and equipment manufactured in the United States. ${ }^{21}$

Examples of the fourth type are loans which are to be made under the recently announced Credit Plan, which has been developed to meet a critical situation growing out of the United States' all-out defense effort. With the tremendous demand here for materials and finished products, producers are in many instances unwilling to assume any of the risks involved in trading with the other Americas. Instead, they insist on payment either in cash or by an irrevocable letter of credit before the product leaves the factory. This means that the purchaser is obliged to assume all risks, including the denial of an export license, the seizure of the product, the lack of shipping space, and the sinking of the ship en route. In view of all these risks in addition to normal risks, purchasers in the other Americas are unable to secure credit with which to finance their purchases. Since many of the products are vitally needed to keep the economic systems of the other American republics functioning, the Export-Import Bank has announced that it will assume these risks by establishing special lines of credit for banks in the other American republics to supplement existing lines. ${ }^{22}$

\section{Matntaining and Improving Transportation Facilities}

\section{Sea Transportation}

By far the most important means of transportation between the United States and the other American republics is by sea. At present land transportation is possible only with Mexico, and even here the bulk of commerce moves by water. Air transportation is expensive and is feasible only for passengers and light-weight articles.

Until 1936 the United States had done little to encourage the development of a first-class merchant marine. Except for a brief period during the First World War, few new ships were built by the United States. A large proportion of our commerce was carried in foreign ships. In 1936 , the Merchant Marine Act of $193^{623}$ was passed in an effort to modernize United States shipping. Instead of the unsatisfactory system of indirect subsidies through mail contracts, the Maritime Commission ${ }^{24}$ is authorized to provide direct construction and operation subsidies. to enable the United States merchant marine to compete with shipping of other nations where wages and other costs are lower than here. ${ }^{25}$

${ }^{21}$ See pp. 676, 677, infra.

${ }^{22}$ Pierson, Solving Two Pan American Trade Problems, 5 For. Commerce Weekly, Nov. x, 1941, p. IO.

${ }_{23} 49$ STAT. 1985 (1936), 46 U. S. C. A. \$rior (Supp. I940).

as Created by Title II of the Merchant Marine Act of 1936 , id. at I985, 46 U. S. C. A. $511 \times x$.

${ }^{25}$ Merchant Marine Act of I936, tits. V, VI, id. at I995-201I, 46 U. S. C. A. \$\$1I5I-1204. 
The Maritime Commission immediately instituted a comprehensive program for the reorganization and modernization of United States shipping. This plan called for the construction, over a ro-year period, of 500 vessels of selected types. A substantial number of the new ships were for inter-American trade. The number of ships operating between the United States and other American ports was increasing up to the outbreak of the war. With the passage of the Neutrality Act of $1939^{26}$ which prohibited United States ships from entering the war zones, ships were transferred from trans-Atlantic routes to inter-American commerce. This assured adequate shipping space for inter-American trade during the early months of the war despite the removal of German ships from the sea lanes and the great increase in interAmerican trade occasioned by the shutting off of European markets and supplies.

But, as the war progressed, severe shipping shortages developed due to a number of causes: (I) the dependence of the other Americas on the United States for supplies; (2) our large purchases of strategic materials from the other Americas; (3) Italy's entry into the war and the occupation of most of Europe, thus removing a large number of vessels from normal trade routes; (4) ship sinkings in the Battle of the Atlantic; (5) the need for a large number of ships to supply Great Britain, China, and Russia with military equipment; (6) the expansion of the United States Army and Navy, and the requisitioning of merchant ships to serve as transports and to carry supplies to army and naval bases; and (7) the transfer of ships to Great Britain.

To relieve the shipping shortage, the Maritime Commission has greatly expanded and speeded up its shipbuilding program. In addition, the seizure of German, Italian, and Danish ships lying in United States ports has helped relieve the shortage. ${ }^{27}$ It will be some time, however, before sufficient ships are available to meet all demands for shipping space. Meanwhile, the Commission has endeavored to provide sufficient shipping space to transport to the other American republics goods vital to the maintenance of their economies as well as products from the other Americas essential to the United States defense program. ${ }^{28}$

The shipping shortage has been particularly acute in the case of tankers. This is due in part to increased demands for petroleum products and in part to sinkings of British tankers to replace which a large number of United States tankers were transferred to Great Britain. This situation has resulted in the curtailment of normal oil

${ }^{30} 54$ STAT. 4 (1939), 22 U. S. C. A. \$245(j) (Supp. 1940).

${ }^{27}$ By Pub. L. No. Ior, 77th Cong., Ist Sess. (June 6, r94x), the President was authorized during the national emergency to take over foreign merchant vessels lying idle in United States waters. By Exec. Order No. 877x, 6 Fed. REg. 2759 (1941), the President directed the Maritime Commission to carry out the provisions of this act. Other American republics have similarly seized idle Axis ships, some of which have been put into service.

${ }^{38}$ Pub. L. No. 173, 77th Cong., Ist Sess. (July I4, 1941), empowers the President, during the emergency, to authorize the Maritime Commission to issue warrants to ships Alying the United States flag, ships Alying forcign flags but owned by United States citizens, or, upon application by foreign owners, ships flying foreign flags. Warrants thus issued entitle the ship to priority over other ships in the use of port facilities. The Commission determines priority rights among ships holding warrants, and in so doing is directed to provide for importing substantial quantities of strategic and critical materials, transporting materials requested by any defense agency, or transporting materials the Commission deems essential to defense. See Exec. Order No. 887I, 6 FED. REg. 4469 ( (I94I). 
shipments in the Americas. In an effort to secure the maximum use of tankers still engaged in American trade, the Petroleum Coordinator for National Defense has recommended measures to assure a minimum quantity of oil for certain Latin American countries. Recommendation II,29 issued July 24, x94I, and directed to certain oil companies, recommended that oil for the Caribbean area, except Cuba, be transported from refineries located at Aruba or Curaçao and not from the United States. Recommendation IX,30 issued August 26, I941, recites that "It is the policy of the United States that the other American Republics shall not sustain an unfair or disproportionate curtailment of petroleum supplies" because of the shortage of tankers, and recommends that sufficient tankers be allocated to supply the other American republics to prevent any such curtailment. Of course, the participation of the United States in the war has made the allocation of shipping space one of the major concerns of the Government and, as a problem of prime importance, is receiving daily consideration.

\section{Air Transportation}

In the field of aviation where the Pan American Airways system has developed extensive air routes serving inter-American needs, the United States has been chiefly concerned with German-operated air lines. These lines were one of the earliest concerns of the Office of the Coordinator of Inter-American Affairs. Prior to September, 1939, Germans owned, operated, or controlled more air route mileage than any other nationality except the United States. ${ }^{31}$ These routes were in Colombia, Ecuador, Peru, Bolivia, Brazil, Argentina, and Uruguay. In addition, the German-owned Condor line operated a trans-Andean line to Chile. For both commercial and military reasons the United States has been anxious to eliminate this German influence. At the same time the United States desires to assist the other American republics to provide for the eventual operation of these German-controlled air lines by local companies and personnel.

At the present time, German control has been eliminated in the Colombian, Ecuadoran, Peruvian, and Bolivian lines. ${ }^{32}$ The Civil Aeronautics Board and the Defense Supplies Corporation have assisted the other Americas in providing new services to replace the German-operated lines. The Civil Aeronautics Board, in

${ }^{20} 6$ FED. REG. 5014 (194I).

${ }^{30} 6$ FED. REG. 5018 (194I).

${ }^{31}$ Then approximately half the air routes in South America were United States owned and over one fifth were German owned or controlled.

${ }^{32}$ In July, 1940, Pan American Airways, owning a majority of the stock of the German-operated SCADTA (Sociedad Colombo-Alemana de Transportes Aereos), which maintained extensive services in Colombia, replaced the German with United States personnel. At the same time SCADTA was merged with a Colombia-owned air line SACO (Servicio Aereo Colombiano). The new company is known as "Avianca" (Aerovias Nacionales de Colombia). As a part of the merger, provision was made for eventual Colombian ownership and operation of Avianca. The Peruvian Government in February, r94I, withdrew the operating permit of Deutsche Lufthansa Sucursal Peru because of flights over forbidden territory. 'To forestall possible sabotage, the line's equipment was seized on April r, r94r. Since "Panagra" maintained a parallel route, there was no need to continue the services of Lufthansa Peru. The Compania Aeronatitica Urugutaya serving Uruguay and the Aeroposta Argentina serving Argentina were never German-owned but, when first started, used German equipment and technicians. This influence is believed no longer present. 
November 1940, amended the certificate of public convenience and necessity ${ }^{33}$ of Pan American-Grace Air Lines (Panagra) so as to enable Panagra to provide regular service between the same cities served by SEDTA, ${ }^{34}$ which since 1937 had maintained air transport services in Ecuador. Thus, when the Government of Ecuador, on September 5, 1941, canceled SEDTA'S concession and expropriated its property because of its inability to obtain the necessary aviation gasoline and the necessary spare parts and equipment for safe operation, Panagra was able immediately to increase its local Ecuadoran operations to include flights between points which had been served by SEDTA.

In May, r94I, the Government of Bolivia eliminated German infuence by nationalizing the German-supported $\mathrm{LAB}^{35}$ which since 1925 had maintained air transport services in Bolivia. The Civil Aeronautics Board again amended Panagra's certificate of public convenience and necessity so as to permit it to operate the main route between $\mathrm{La}$ Paz and Corumba, Brazil. The newly nationalized LAB will continue to operate the interior routes. To provide an improved service, the Defense Supplies Corporation has extended a loan to enable LAB to acquire modern flight equipment and ground facilities. ${ }^{36}$

Since the outbreak of the war, II,403 miles of German-owned or operated air lines on the west coast of South America have been eliminated. ${ }^{37}$ The only remaining German-controlled west coast line is the 870-mile trans-Andean route. All but the Peruvian line, which merely duplicated services provided by Panagra, are still in operation, but under United States or local control.

\section{Land Transportation}

The construction of a Pan American Highway has long been considered an important contribution to the welfare of the people of the Western Hemisphere. By providing comparatively cheap transportation and communication facilities, the Highway should aid substantially in the development of vast resources now inaccessible. It will also increase tourist traffic, now hampered by the high cost of air transportation and the slowness of steamship transportation.

As of June, 1941, $85 \%$ of the 9,238-mile route from Nuevo Laredo, Mexico, on the United States border to Buenos Aires via Chile was passable in dry weather, and $75 \%$ in all weather. Of the $8,9 \mathrm{I}_{4}$-mile route to Buenos Aires via Bolivia, $8 \mathrm{I} \%$ was passable

\footnotetext{
${ }^{33}$ The Board is authorized to gxant such certificates by the Civil Aeronautics Act of I938, 52 STAT. 987,49 U. S. C. A. $\$ 48$ I (Supp. I940).

${ }^{34}$ Sociedad Ecuatoriana de Transportes Aereos. ${ }^{35}$ Lloyd Aereo Boliviano.

${ }^{30}$ Pub. L. No. 108, 77th Cong., Ist Sess. (June Io, I94I), authorizes the RFC, when requested by the Federal Loan Administrator, with the approval of the President, to organize corporations to take such other action, in addition to action specifically authorized by an amendment approved June 25, 1940, 54 Stat. 573 (1940), 15 U. S. C. A. $\$ 606 \mathrm{~b}$ (Supp. 1940) (see note 49 , infra) as the President and the Administrator deem necessary to expedite the national defense program. The charter of the Defense Supplies Corporation was amended on July 9, I94I, so as to include this additional grant of power. 6 FED. REG. 3363 (194r).

${ }^{37}$ The total route mileage was distributed as follows: Bolivia, 4,109; Columbia, 5,494; Ecuador, 590; Peru, $x, 210$.
} 
in dry weather, and $63 \%$ in all weather. The impassable sections were in Mexico, Honduras, Nicaragua, Costa Rica, Panama, Colombia, and Argentina.

While the Pan American Highway is being financed mainly by the countries through which it passes, the United States has cooperated in all phases. Through the Public Roads Administration, valuable technical assistance has been rendered.98 Financial aid has also been given the countries through which the proposed highway will run, both for surveys and actual construction. ${ }^{39}$ Recently, the Export-Import Bank has made substantial loans to enable the local governments to proceed with the construction of the Highway. ${ }^{40}$ A Convention has been signed with Panama providing for the construction of the Trans-Isthmian section. ${ }^{41}$

An act has very recently been passed appropriating $\$ 20$ million to aid Costa Rica, El Salvador, Guatemala, Honduras, Nicaragua, and Panama in the survey and construction of the section of the Highway running through these countries. ${ }^{42}$ Under this act, the United States assumes two thirds of the construction cost and the republics named the other one third. The recently announced agreement with Mexico provides for a $\$ 30$ million loan by the Export-Import Bank to finance the completion of the Mexican section of the Pan American Highway and other important roads. ${ }^{43}$ The United States has also contributed to the construction of other important land communications in South America. Thus, the Export-Import Bank has recently loaned $\$ 3$ million to aid in the construction of a highway in Paraguay. The Bank has also extended credits to finance the purchase in the United States of equipment for the construction and operation of railroads.

\section{Other Governmental Activities Implementing the Good Neighbor Policy}

Other types of assistance and cooperation in developing a mutual prosperity among the American republics are being undertaken. Numerous governmental agencies, when requested by other.American republics, have sent experts to assist the local governments in solving special problems. ${ }^{44}$ Thus, the Bureau of Mines of

${ }^{38}$ Beginning in 1930 , Administration engineers have made surveys in Panama, Costa Rica, Nicaragua, Honduras, and Guatemala.

${ }^{30}$ The following funds have been appropriated by Congress to date:
Date
Amount
Purpose

March 26, 1930.......\$ 50,000 Reconnaissance surveys-45 STAT. I697; 46 STAT. I15

June 18, r934......... 75,000 Reconnaissance surveys -48 StAr. 996

June $19,1934 \ldots \ldots \ldots \ldots$ 1,000,000 Surveys and construction-48 STAT. 1042

March 5, r $938 \ldots \ldots \ldots \ldots .34,000$ Administrative funds -52 STat. 88

June 25, r938......... 50,000 Engineering advice and assistance-52 STAT. $1 \times 46$

August 9, 1939........ 40,000 Engineering advice and assistance-53 STAT. 1305

…......... 1,500,000 Construction of section in Panama-53 STAT. 1071, 1327

April 18, r940......... 75,000 Surveys and construction-54 Star. I29

April 5, 1941.......... 100,000 Surveys and construction-Pub. L. No. 28, 77th Cong., 1st Sess.

\section{$\$ 2,924,000$}

${ }^{40}$ Loans totalling $\$ 9,700,000$ have been made by the Bank as follows: Costa Rica, $\$ 4,600,000$; Nicaragua, \$r,700,000; Panama, \$2,500,000; Ecuador, \$r,900,000.

153 STAT. I869-1873 (1936).

2 Pub. L. No. 275, 77th Cong., Ist Sess. (Dec. 26, 1941).

4s Agreement, art VI, N. Y. Times, Nov, 20, I94I, p. 4.

"For the authority for such action, see note 6 , supra. 
the Department of Interior has loaned experts to assist in the development of mines in Argentina, Brazil, Bolivia, Chile, and Peru. Similarly, the Fish and Wild Life Service of the Department of Interior has sent fishing experts to Mexico and Peru. ${ }^{45}$ The Geological Survey, also a part of the Department of the Interior, has sent representatives to conduct surveys in Bolivia, Brazil, Colombia, Costa Rica, Cuba, Guatemala, Panama, and Venezuela. The Children's Bureau of the Department of Labor has sent specialists in child welfare to assist in setting up child welfare services in Brazil and Paraguay. A representative of the Women's Division of the Department of Labor has assisted the governments of Chile, Argentina, and Uruguay. A representative of the Tariff Commission has been detailed to Paraguay. Specialists of the Department of Agriculture have been sent to the other Americas to help in the control of the dissemination of plant and animal diseases. The Public Roads Administration has sent experts to Bolivia and Ecuador and has assisted the Central American Republics in the construction of the Pan American Highway.

To promote inter-American trade and to assist the other American republics in training their citizens in technical fields, certain governmental agencies have made available reports, studies, surveys, etc., dealing with a wide variety of subjects. Thus, the Department of Commerce has assembled detailed information on all phases of inter-American trade. The Tariff Commission is publishing Spanish and English editions of a study entitled "The Foreign Trade of Latin America." The Department of Labor has published Spanish and Portuguese editions of "The Woman Worker in the United States." The Civil Aeronautics Administration has made available to the heads of the Departments of Aviation in the other American republics copies of the United States Civil Air Traffic Regulations and copies of a Flight Instructor's Manual.

An important contribution to hemispheric prosperity is the opportunity being afforded citizens of the other American republics to come to the United States for technical training and to learn how certain governmental problems are being handled in this country. Many such programs have been initiated, aided, or sponsored by the Office of the Coordinator of Inter-American Affairs. The most ambitious program of this type is in the field of aviation. As a counterpart to the elimination of Germancontrolled air lines, discussed above, the United States is assisting in the development of locally owned and operated air lines. At present, there is insufficient trained personnel among the local populations to operate the air lines formerly operated by the Germans.

During the winter of $1940-194 \mathrm{I}$, as an experiment, more than twenty persons from the other American republics received training in pilot training schools set up under the Civilian Pilot Training Program. ${ }^{46}$ The experiment was regarded as a success,

\footnotetext{
${ }^{6}$ This survey has led to the expansion of Peruvian commercial fishing; a plant is being erected to freeze and can fish; outlets for retail sale of fish are being expanded; and plans are under way to develop a fish meal and oil industry.

${ }^{40}$ The Civilian Pilot Training Act, 53 STAт. 856 (I939), 49 U. S. C. \$757 (Supp. 1940), \$7, limits funds appropriated thereunder to the training of United States citizens. However, the State Department made available $\$ 20,000$ to pay for the training of these pilots.
} 
and this year has been greatly expanded. The recently announced program for the coming year contemplates the training of over 500 citizens from the other American republics. One hundred persons will receive pilot training from the Army Air Corps, and the balance will be trained at Civilian Pilot Training Schools. ${ }^{47}$ Some of the persons receiving training at the latter schools will be trained as pilots, while others will be trained to be aeronautical engineers, airplane service mechanics, and instructor mechanics.

The Children's Bureau of the Department of Labor, the Public Health Service, the Rural Electrification Administration, the Department of Agriculture, the Tariff Commission, and the Smithsonian Institution have all assisted in scholarship programs and in tours to points of special interest for selected groups of citizens of the other Americas.

Another important contribution to trade and the improvement of living conditions is the furnishing of adequate communications facilities. With this aim in view, the Federal Communications Commission passes on applications for furnishing inter-American radio, telephone, telegraph, and cable facilities. ${ }^{48}$ Before approving applications, the FCC requires that the applicant demonstrate the necessity for the proposed facility and its ability to comply with regulations and standards prescribed by that agency.

Since it is felt that increased travel will result in increased trade, both by familiarizing the citizens of each country with their neighbors, and, when United States citizens travel in the other Americas, by providing additional dollar exchange for the purchase of United States products, steps in addition to those mentioned above have been taken to improve travel facilities. The Maritime Commission has endeavored to bring steamship rates within reach of more persons. The United States Travel Bureau of the National Park Service, administered by the Department of the Interior, has distributed travel literature concerning the United States in the other Americas. With the Hemisphere now directly involved in the war, this program has necessarily been curtailed.

\section{Providing for the Defense of the Hemisphere}

Three corporations were formed about the middle of $194^{\circ}$ by the Reconstruction Finance Corporation in order to accumulate reserves of materials vital to the rearmament program and defense needs:48 The Metals Reserve Company, the Rubber Reserve Corporation, and the Defense Supplies Corporation. ${ }^{00}$ These corporations

67 The necessary training personnel is being provided by the Army Air Corps and the Civil Acronautics Authority. The cost of bringing the trainees here and training them will be borne primarily by the Defense Supplies Corporation. See note 36, supra. The Army Air Corps, the Civil Aeronauties Authority, and the Coordinator of Inter-American Affairs are assisting in the financing.

s8 The FCC's authority is conferred by the Communications Act of 1934, as amended. 48 STAT. 1064 (1934), 50 STAT. I89 (I937), 47 U. S. C. \$I5I (Supp. 1940).

${ }^{69}$ The Reconstruction Finance Corporation Act was amended on June 25, $x 940$, to give the RFC authority, when requested by the Federal Loan Administrator with the approval of the President, to create corporations to acquire strategic and critical materials. 54 Star. 573 (1940), X5 U. S. C. A. $\$ 606 \mathrm{~b}(2)$ (Supp. I940).

${ }^{\circ 0}$ The Rubber Reserve Corporation and the Metals Reserve Company were created June 28, 1940, 
have adopted a policy of purchasing all strategic and critical materials from the other American republics which are not being purchased through normal channels. The corporations in no sense compete with private purchasers, but attempt to secure as reserve stocks for the United States materials over and above present demands.

Materials already purchased or contracted for by these three corporations include bauxite, copper, diamond dies, industrial diamonds, lead, tungsten, leather, manganese, mercury, nitrates, platinum, quartz, crystals, rubber, tin, and zinc. Purchases have been made from eight of the American republics. ${ }^{51}$

Besides building up reserve stocks of strategic and critical materials, these three corporations play an important role in the war program by arranging to take from the other Americas all exportable quantities of these materials not purchased by United States importers. This makes it increasingly difficult for these materials to reach the hands of unfriendly powers, and to that extent supplements the blockade of the Axis powers. This program is being carried out by the corporations with the aid of the State Department and takes the form of long-term contracts of purchase. In some instances, the contract is strengthened by local export licenses which are granted only for exports to countries in the Western Hemisphere.

Another important phase of the Government's hemispheric program affecting inter-American trade is the establishment of a Proclaimed List of Certain Blocked Nationals. On July I7, I94I, the President, by Proclamation, authorized the Secretary of State, in conjunction with the Secretary of the Treasury, the Attorney General, the Secretary of Commerce, the Economic Defense Board, and the Coordinator of Inter-American Affairs ${ }^{52}$ to prepare a list of persons with German or Italian sympathies and persons whose activities are deemed detrimental to the interests of national defense. ${ }^{53}$ Such a list was promulgated and published on the same day. ${ }^{54}$ Persons or firms appearing on the list are regarded as nationals of Germany or Italy and, as such, United States citizens are prohibited from extending them credit. In addition, exporting to any person appearing on the List of any article subject to Export Control ${ }^{55}$ is prohibited. This, of course, is intended to curtail such persons'

6 FEd. ReG. 297I (I94I). The Defense Supplies Corporation was created on Aug. 29, I940, and its powers broadened on Feb. 15, x94 6 Fed. ReG. 2972 (I94I), and again on July 9, I941, 6 FED. REg. 3363 (I94I), pursuant to Pub. L. No. 108, 77th Cong., rst Sess. (June Io, I94I).

¿1 Argentina, Bolivia, Brazil, Chile, Colombia, Cuba, Mexico, Peru.

${ }^{2}$ The Coordinator of Inter-American Affairs was established July 30, 1941, by Executive Order of the President, No. 8840,6 FED. REg. 3857 , and succeeded to all the rights of the Office of the Coordinator of Commercial and Cultural Relations Between the American Republics, which Office had been established on Aug. 16, 1940, by order of the Council of National Defense. 5 FED. REg. 2938 (x940).

${ }^{53} 6$ FED. REg. 3555 ( $194 \mathrm{I}$ ). The proclamation was issued pursuant to $(\mathrm{I})$ the Trading with the Enemy Act of Oct. 6, I9I7, \$5(b), as amended, 40 STAT. 4I5 (I9I7), 40 STAT. 966 (I9I8), 48 StAT. I (1933), 54 Stat. 779 (1940), 50 U. S. C. A. App. \$5(b) (Supp. 1940), which authorizes the President, during a time of war or other national emergency declared by him, to investigate, regulate, or prohibit transactions by persons subject to the jurisdiction of the United States in which any foreign state or a national or political subdivision thereof, as defined by the President, has any interest; (2) the Act of July 2, 1940, $\$ 6,54$ STaT. 714, 50 U. S. C. A. $\$ 99$ (Supp. 1940), (see note 63 , infra); (3) the national emergency; and (4) "all other authority vested in" the President.
E 6 FED. REG. 3557-3573 (x94r).
${ }^{56}$ See note 63 , infra. 
business and limit the funds available for carrying on activities in behalf of governments hostile to the United States.

From time to time additions to and deletions from the list are made. Prior to the outbreak of war with Japan there had been four supplements to the original list. ${ }^{56}$ On December I0, I94 I, a Fifth Supplement was issued adding Japanese persons or firms, ${ }^{57}$ and on December 23, I94I a Sixth Supplement was authorized..$^{58}$

\section{The Situatron As of January, 1942}

The problem of providing sufficient raw materials and finished products to maintain the economic life of the other Americas, of locating and acquiring vital war materials from the other American republics, and of providing adequate shipping facilities to transport these goods has become increasingly complex as the war program progresses. More and more materials are being sent to Great Britain, Russia, and China. Increasing quantities of goods are required by the United States Army and Navy. Additional shipping space is necessary to transport materials to and from the other American republics.

As the productive capacity of the United States became geared to turning out supplies under the Lend-Lease Act and material for our own armed forces, the need of a central agency to allocate material and shipping facilities became evident. On July 30, 1941, by Executive Order, ${ }^{59}$ the President established the Economic Defense Board with far-reaching powers with respect to economic defense. ${ }^{.0}$ As originally constituted, the Economic Defense Board was exclusively a policy-forming agency, administration being left to existing agencies. ${ }^{61}$ On September 15, x941, additional powers and responsibilities were vested in the Economic Defense Board. ${ }^{02}$ These additional duties include the administration of Export Control ${ }^{63}$ and the determination of the types and amounts of materials and commodities, other than Lend-Lease

${ }^{56}$ July 28, I94I, 6 Fed. REg. 3773-3774; Sept. 25, I94I, 6 FED. REG. 4915-4920; Nov. 7, 1941, 6 FED. REG. 5722-5728; Dec. 4, I94I, 6 FED. REg. 6204-6206.

${ }^{67} 6$ Fed. Reg. 635I-6354.

${ }^{59}$ Exec. Order No. 8839, 6 FED. REg. 3823 (1941). The Board, as originally established, was composed of the Vice President as Chairman, the Secretaries of State, War, Navy, Agriculture, and Commerce, and the Attorney General.

"EO "Economic Defense" is defined by paragraph 1 of the Executive Order as "the conduct, in the interest of national defense, of international economic activities, including those related to exports, imports, the acquisition and disposition of materials and commodities from foreign countrics, including preclusive buying, transactions in foreign exchange and foreign-owned or foreign-controlled property, international investments and extensions of credit, shipping and transportation of goods among countries, the international aspects of patents, and international communications pertaining to commerce, and other foreign economic matters." 6 FED. REg. 3823 (I94I).

${ }^{01}$ Exec. Order No. 8839, par. 4, 6 FED. REg. 3823 (I94I).

${ }^{02}$ Exec. Order No. 8900, 6 Fed. Reg. 4795 (I94I).

${ }^{63}$ By $\$ 6$ of the Act of July 2, I940, 54 STAT. 714 (1940), 50 U. S. C. A. $\$ 99$ (Supp. I940), the President is authorized in the interests of national defense to prohibit or curtail the exports of military equipment or munitions, or component parts thereof, or machinery, tools, or supplies necessary for the manufacturing, servicing, or operation thereof. Export Control includes all territories, dependencies, and possessions of the United States, including the Philippine Islands. Pub. L. No. 75, 77th Cong., 1st Sess. (May 28, I94I). Export Control had previously been administered separately by Lieut. Col. Maxwell, acting under a Milizary Order of July 2, 1940, 5 FED. REG. 249 I (1940). 
supplies, which should be made available for export to other countries in the interest of economic defense.

In the inter-American field, the Coordinator of Inter-American Affairs cooperated with the Economic Defense Board in administering these duties. In the Executive Order of the President creating the Office, the Coordinator was charged inter alia with the duty of formulating, recommending and executing "programs in the commercial and economic fields which, by the effective use of governmental and private facilities, will further the commercial well-being of the Western Hemisphere." In discharging its responsibility, this Office has been interested in all phases of trade relationships, and it has sponsored and financed many of the programs outlined, but in most instances the actual operations of the Coordinator's Office have been conducted through other governmental or private agencies. Ironing out difficulties in export licenses, advocating new credit plans, studying the problems of foreign bondholders, dealing with shortages of shipping space, finding new markets for the products of the other American republics, and locating new sources of strategic and critical materials are a few of its most recent operations in the commercial field.

On November 22, 1941, the Vice President, as Chairman of the Economic Defense Board, announced the appointment of the Coordinator of Inter-American Affairs as a member of the Economic Defense Board, and the establishment of four divisions of the Board, including the American Hemisphere Division. ${ }^{64}$ The American Hemisphere Division, which was formed by a merger of the personnel of the Economic Defense Board engaged in the inter-American field with the Commercial and Financial Division of the Coordinator's Office, will be responsible among other things, for securing vital supplies from sources in this hemisphere, as well as for assuring the other American republics materials and products essential to the maintenance and development of their economy.

After the declaration of war, the Economic Defense Board's name was changed to the Board of Economic Warfare. ${ }^{.5}$ The arrival of war finds the combined agencies equipped with the powers and the trained personnel necessary to fulfil the increased responsibilities war imposes.

\section{CoNCLUSION}

The measures which have been taken to further the trade of the Americas have immeasurably strengthened the ties between them and have laid a firm foundation for the war effort. The United States is fast becoming the "arsenal of democracy" but, since many vital raw materials are found only in the other American republics, it is only by maintaining our trade relationships that we can look forward to eventual victory.

\footnotetext{
${ }^{04}$ N. Y. Times, Nov. 23, I94x, p. 47. The other three Divisions are the European and African Division, the Far Eastern Division, and the British Empire Division.

${ }^{\circ 5}$ Exec. Order No. 8982, 6 Fed. Reg. 6530 (1941).
} 